\title{
Hubungan Game Online terhadap Kemampuan Berpikir Kritis Matematis Siswa Kelas VIII SMP N 1 Ampek Angkek Tahun Pelajaran 2018/2019
}

\author{
Rahmadila ${ }^{1}$, M. Imamuddin ${ }^{2}$, Haida Fitri ${ }^{3}$ \\ ${ }^{1,2,3}$ Program StudiPendidikan Matematika, Institut Agama Islam Negeri Bukittinggi \\ e-mail:rahmadilapmtk@gmail.com
}

\begin{abstract}
ABSTRAK. Penelitian ini dilatarbelakangi oleh hasil observasi peneliti di SMP N 1 Ampek Angkek dimana banyak siswa menjadi pemain dalam game online walaupun mereka bermain game online mereka masih mendapatkan nilai yang di atas KKM dalam sekolahnya. Penelitian ini bertujuan untuk mengetahui hubungan game online dengan kemampuan berpikir kritis matematis siswa yang dilaksanakan di SMPN 1 Ampek Angkek. Penelitian ini adalah penelitian kuantitatif dengan jenis korelasi. Variabel bebas dalam penelitian ini adalah game online dan variabel terikat adalah kemampuan berpikir kritis siswa. Populasi dalam penelitian ini berjumlah 114 siswa, dengan jumlah sampel 29 siswa yang dipilih secara acak. Berdasarkan hasil penelitian diperoleh nilai hubungan Pearson Product Moment, $r_{\text {hitung }}=0,068$ pada taraf signifikansi 0,05. Berdasarkan interpretasi koefisien hubungan nilai $r$ terletak pada selang $0,00<0,068<0,199$ yang berarti korelasi antara kedua variable (game online dengan kemampuan berpikir kritis) tergolong sangat rendah. Berdasarkan uji signifikansi diperoleh sig $=0,728$. Karena nilai $\operatorname{sig}=0,728>\alpha=$ 0,05 maka dapat disimpulkan terdapat hubungan yang tidak signifikan antara game online dengan kemampuan berpikir kritis matematis siswa SMPN 1 Ampek Angkek
\end{abstract}

Kata kunci: Game online, kemampuan berpikir kritis matematis, korelasi

\section{PENDAHULUAN}

Berpikir kritis menurut Ennis adalah proses berpikir yang harus dilakukan seseorang atau individu dengan tujuan untuk mengambil keputusan yang masuk akal terkait dengan keyakinan dan dapat dilakukan dengan benar (Wewe, 2017). Berpikir kritis merupakan kemampuan seseorang atau individu untuk benar-benar menganalisa setiap tindakan dan perbuatan yang akan diambilnya. Hal ini dapat membantu seseorang untuk mengevaluasi setiap keputusan dan tindakan yang mereka lakukan sehingga mereka tidak salah dalam tindakan yang mereka lakukan.Menurut Ennis aspek berpikir kritis matematis memiliki beberapa indikator sebagai berikut: 1) memberi penjelasan dasar (klasifikasi), 2) membangun keterampilan dasar, 3) menyimpulkan, 4) memberi penjelasan lanjut dan 5) mengatur strategi dan taktik (Ikhsan \& Rizal, 2014). Berpikir kritis merupakan dasar dari suatu proses berpikir untuk membuat analisis dengan memunculkan ide-ide terhadap tindakan yang dilakukan sehingga mengembangkan pola pikir yang logis. Hal ini juga diungkapkan oleh Noer yaitu berpikir kritis matematis merupakan proses yang mengarah pada penarikan kesimpulan yang harus diambil terhadap tindakan yang dilakukan (Jumaisyaroh, Napitupulu, \& Hasratuddin, 2015).

Pada saat sekarang ini banyak siswa yang senang bermain game online. Game online adalah permainan yang menggunakan jaringan internet untuk mengaksesnya dan dapat dimainkan dengan siapapun tanpa dibatasi oleh sekat geografis dan waktu (Hanum, 2013). Game online sendiri terdiri dari berbagai jenis, mulai permainan sederhana berbasis teks hingga permainan yang menggunakan grafik kompleks dan membentuk dunia virtual yang ditempati oleh banyak pemain sekaligus (Surbakti, 2017). Kebanyakan siswa bermain game online karena mendapatkan 
tantangan saat bermain game online, game-nya seru, serta variatif sehingga mereka rela mengeluarkan uang dan waktu untuk menikmati game yang mereka minati tersebut. Tidak jarang karena kasus ini banyak siswa yang lupa dengan tugas dan kewajiban mereka sebagai pelajar dan bahkan tidak jarang nilai mereka menjadi jelek. Namun tidak semua pemain game online lupa dengan kewajiban sebagai pelajar. Ada dari mereka yang bermain game online bisa mengatur waktu sehingga tidak membawa dampak yang buruk bagi nilai akademik.

Ilmu pengetahuan dan teknologi yang semakin berkembang pesat memungkinkan seseorang dengan mudah memperoleh infomasi secara cepat dan mudah, untuk itulah kemampuan berpikir kritis diperlukan baik itu pelajar maupun non pelajar dan tidak terbatas oleh kalangan manapun baik itu umur dan gender. Sekarang, orang-orang bisa dengan mudahnya mengakses informasi dari berbagai belahan dunia dan kita bisa melakukannya dimana saja dan kapan saja. Hal ini tentu saja memberikan dampak positif dan dampak negatif bagi penggunanya. Dampak positif yang didapat salah satunya, memudahkan kita untuk berinteraksi dengan seseorang melalui media sosial, mendapatkan hiburan seperti MP3 dan game online apabila kita sedang membutuhkan refreshing. Dampak negatif yang didapat, salah satunya adalah antisocial sehingga mereka jarang berinteraksi langsung dengan orang didunia nyata dan tidak jarang mereka mengabaikan kesehatan mereka sendiri karena terlalu asik dengan smartphone atau gadget yang mereka miliki dengan begitu banyak fitur aplikasi yang telah tersedia (Effendi \& Junaidi, 2014).

Seperti halnya dalam buku Ayu Rini "Menanggulangi Kecanduan Game Online Pada Anak" menyebutkan penelitian yang dilakukan oleh beberapa peneliti dari Universitas Rochestes, New York terhadap para pecandu game online. Hasil yang didapat sungguh mengejutkan karena ternyata orang yang pemain game online memiliki fokus terhadap apa yang terjadi disekitarnya daripada mereka yang jarang bermain game. hasil penelitian ini juga menunjukkan bahwa pecandu game kebanyakan adalah orang yang berinteligensi tinggi, memiliki motivasi yang tinggi dan berorientasi pada prestasi. Prestasi mereka disekolah terbilang bagus dan tidak terganggu dengan hobi mereka dalam bermain game(Rini, 2011).

Dalam jurnal modern psychological studies Universitas of the Cumberlands, Smyth menyarankan, permainan yang kompleks dapat menghasilkan kesuksesan akademik dengan melibatkan pemain dalam pemecahan masalah, pemikiran kritis, dan kreativitas (Wright, 2011)Diantaranya permainan game online yang menggunakan grafik kompleks berupa: 1) Massively Multiplayer Online First Person Shotter Games (MMOFPS) game online jenis ini mengambil sudut pandang orang pertama sehingga seolah-olah pemain berada dalam permainan tersebut dalam sudut pandang tokoh karakter yang dimainkan, dimana setiap tokoh memiliki kemampuan yang berbeda dalam tingkat akurasi, refleks, dan lainnya. permainan ini dapat melibatkan banyak orang dan biasanya permainan ini mengambil setting peperangan dengan senjata-senjata militer. Contoh permainan jenis ini antara lain Counter Strike, Call of duty, Point Blank, dst. 2) Massively Multiplayer Online Real-time strategy games (MMORTS).Game jenis ini menekankan kepada kehebatan strategy pemainnya. Permainan ini memiliki ciri khas dimana pemain harus mengatur strategy permainan. 3) Massively Multiplayer Online Role-Playing Games (MMORPG). Game jenis ini biasanya memainkan peran tokoh - tokoh khayalan dan berkolaborasi untuk merajut sebuah cerita bersama, contoh dota, final fantasy. 4) Massively Multiplayer Online Browser Game. game jenis ini dimainkan pada browser seperti mozilla firefox, opera, atau internet explorer. 5) Massively Multiplayer Online Games (MMOG). Pemain bermain bermain dalam dunia yang skalanya besar (>100 pemain) dimana setiap pemain dapat berinteraksi langsung seperti dunia nyata, sehingga memungkinkan ratusan, bahkan ribuan pemain untuk bermain bersama - sama. Maka dari MMOG ini akan dibentuk MMORPG, MMORTS, MMOFPS, dan MMOSG (Surbakti, 2017).

Seorang anak yang tidak bisa mengontrol waktunya dalam bermain game online dapat berdampak menjadi pecandu (adiktif) dan lebih mementingkan bermain game online dibandingkan dengan kegiatan yang lain, Menurut Brown seorang anak dikatakan pecandu (adiktif) apabila memenuhi minimal tiga dari enam kriteria sebagai berikut: 1) Salience yaitu menunjukkan dominasi aktivitas bermain game dalam pikiran dan tingkah laku. Salience dibagi menjadi dua yaitu: a. Cognitive 
salience yaitu dominasi aktivitas bermain game pada level pikiran, b. Behavioral salience yaitu dominasi aktivitas bermain game online pada level tingkah laku. 2) Euphoria yaitu mendapatkan kesenangan dalam aktivitas bermain game. 3) Conflict yaitu pertentangan yang muncul antara pecandu dengan orang-orang yang ada disekitarnya (external conflict) dan juga pertentangan dengan dirinya sendiri (internal conflict) yang disebabkan tingkah laku yang berlebihan. 4) Tolerance yaitu aktivitas bermain game online mengalami peningkatan secara progresif selama rentang priode untuk mendapatkan efek kepuasan. 5) Withdrawal yaitu perasaan tidak menyenangkan ketika tidak melakukan aktivitas bermain game online. 6) Relapse and reinstatement yaitu kecendrungan untuk melakukan pengulangan terhadap pola-pola awal tingkah laku pecandu atau bahkan menjadi lebih parah. Hal ini menunjukkan kecendrungan ketidakmampuan untuk berhenti secara utuh dari aktivitas bermain game online (Jenab \& Hudaya, 2015).

Penelitian serupa pernah diteliti oleh Krista Surbakti dengan judul "Pengaruh Game Online Terhadap Remaja". Teknik pengumpulan data yang digunakan berupa angket dengan metode analisis deskriptif. Didalam penelitian ini Krista Surbakti menjelaskan bahwa terdapat dampak positif dan dampak negatif dari bermain game online.

Diantaranya dampak positif bermain game online berupa: 1) Menambah intelegensia, 2) Menambah konsentrasi, 3) Meningkatkan ketajaman mata, 4) Meningkatkan kemampuan berbahasa inggris, 5) Membantu bersosialisasi, 6) Meningkatkan kinerja otak, 7) Meningkatkan kecepatan mengetik, 8) Menghilangkan stress, 9) Memulihkan kondisi tubuh. Selain dampak positif, dampak negatif yang ditimbulkan dari bermain game online berupa: 1) Menimbulkan adiksi (kecanduan), 2) Mendorong melakukan hal-hal negatif, 3) Berbicara kasar dan kotor, 4) Terbengkalainya kegiatan di dunia nyata, 5) Perubahan pola makan dan istirahat, 6) Pemborosan, 7) Menganggu kesehatan (Surbakti, 2017).

Penelitian sebelumnya yang diteliti oleh Mohammad Seifi, "The Effect of Computer Games On Students' Critical Thinking Disposition and Educational Achievement". Penelitian yang dilakukannya bersifat deskriptif dengan jenis penelitian penyebab-komparatif. Sampel diambil secara acak menggunakan multistage clustering . Mohammad Seifi mengatakan, The finding of the research showed that playing computer games has a positive significant effect on students' educational achievement, but has no significant effect on critical thinking disposition. Likewise, the results showed that different types of computer games was no significant effects on students' critical thinking and their educational achievement (Seifi, 2015). Menurutnya, penelitian terhadap Effect of Computer Games On Students memberikan dampak yang positif yang signifikan terhadap prestasi siswa tetapi tidak memiliki hasil yang signifikan terhadap kemampuan berpikir kritis siswa.

Pada artikelini peneliti akan melihat hubungan game online dengan kemampuan berpikir kritis matematis siswa siswa kelas VIII SMP N 1 Ampek Angkek. Apakah ada hubungan antara kemampuan berpikir kritis matematis siswa dengan bermain game online.

\section{METODE}

Penelitian ini merupakan penelitian korelasional dimana peneliti melihat hubungan game online dengan kemampuan berpikir kritis matematis siswa kelas VIII SMPN 1 Ampek Angkek. Populasi dalam penelitian ini diambil dari siswa yang bermain game online sebanyak 114 siswa yang kemudian diambil sampel secara acak (random sampling) sebanyak 29 siswa pemain game online. Variabel penelitian ini terdiri atas 2 variabel yaitu variabel bebas dan variabel terikat, variabel bebasnya adalah game online dan variabel terikatnya adalah kemampuan berpikir kritis matematis siswa.

Tahapan dalam penelitian ini dimulai dengan; 1) Melakukan observasi terkait siswa/i yang bermain game online, 2) Meminta data nilai UAS 2017/2018, 3) Menyusun instrumen yang akan digunakan untuk penelitian yaituangket game online dan kemampuan berpikir kritis siswa, 4)

Memvalidasi instrumen kepada ahli, 5) Melakukan uji coba angket dan soal tes kemampuan berpikir kritis yang sudah divalidasi, 6) Memberikan angket game online yang kisi-kisinya mengacu 
pada pendapat Brown. 7) Memberikan tes kemampuan berpikir kritis matematis kepada siswa yang merupakan pemain game online.

Untuk melihat siswa yang merupakan pecandu game online maka digunakan kriteria menurut Brown yang menyatakan bahwa siswa dikatakan pecandu apabila memenuhi tiga dari enam kriteria yaitu; 1) Salience, 2) Euphoria, 3) Conflict, 4)Tolerance, 5)Withdrawal, 6)Relapse and reinstatement. (Jenab \& Hudaya, 2015)

Tabel 1. Indikator Kemampuan Berpikir Kritis Matematis Siswa

\begin{tabular}{|c|c|}
\hline Indikator Umum & Indikator \\
\hline Menginterpretasi & $\begin{array}{l}\text { Memahami masalah yang ditujukan dengan menulis diketahui maupun } \\
\text { ditanyakan soal dengan tepat }\end{array}$ \\
\hline Menganalisis & $\begin{array}{l}\text { Mengidentifikasi hubungan-hubungan antara pernyataan-pernyataan, } \\
\text { pertanyaan-pertanyaan, dan konsep-konsep yang diberikan dalam soal yang } \\
\text { ditunjukkan dengan membuat model matematika dengan tepat dan } \\
\text { memberi penjelasan dengan tepat }\end{array}$ \\
\hline Mengevaluasi & $\begin{array}{l}\text { Menggunakan strategi yang tepat dalam menyelesaikan soal, lengkap dan } \\
\text { benar dalam melakukan perhitungan }\end{array}$ \\
\hline Menginferensi & Membuat kesimpulan dengan tepat \\
\hline
\end{tabular}

Tabel 2. Pedoman Penskoran Kemampuan Berpikir Kritis Matematis Siswa

\begin{tabular}{|c|c|c|}
\hline Indikator Umum & Indikator & Skor \\
\hline \multirow{5}{*}{ Interpretasi } & Tidak menulis yang diketahui dan yang ditanyakan & 0 \\
\hline & Menulis yang diketahui dan yang ditanyakan dengan tidak tepat & 1 \\
\hline & $\begin{array}{l}\text { Menuliskan yang diketahui saja dengan tepat atau yang ditanyakan } \\
\text { saja dengan tepat }\end{array}$ & 2 \\
\hline & Menulis yang diketahui dari soal dengan tepat tetapi kurang lengkap & 3 \\
\hline & $\begin{array}{l}\text { Menulis yang diketahui dan ditanyakan dari soal dengan tepat dan } \\
\text { lengkap }\end{array}$ & 4 \\
\hline \multirow{5}{*}{ Analisis } & Tidak membuat model matematika dari soal yang diberikan & 0 \\
\hline & $\begin{array}{l}\text { Membuat model matematika dari soal yang diberikan tetapi tidak } \\
\text { tepat }\end{array}$ & 1 \\
\hline & $\begin{array}{l}\text { Membuat model matematika dari soal yang diberikan dengan tepat } \\
\text { tanpa memberi penjelasan }\end{array}$ & 2 \\
\hline & $\begin{array}{l}\text { Membuat model matematika dari soal yang diberikan dengan tepat } \\
\text { tetapi ada kesalahan dalam penjelasan }\end{array}$ & 3 \\
\hline & $\begin{array}{l}\text { Membuat model matematika dari soal yang diberikan dengan tepat } \\
\text { dan memberi penjelasan yang benar dan lengkap }\end{array}$ & 4 \\
\hline \multirow{5}{*}{ Evaluasi } & Tidak menggunakan strategi dalam menyelesaikan soal & 0 \\
\hline & $\begin{array}{l}\text { Menggunakan strategi yang tidak tepat dan tidak lengkap dalam } \\
\text { menyelesaikan soal }\end{array}$ & 1 \\
\hline & $\begin{array}{l}\text { Menggunakan strategi yang tepat dalam menyelesaikan soal, tetapi } \\
\text { tidak lengkap atau menggunakan strategi yang tidak tepat tetapi } \\
\text { lengkap dalam menyelesaikan soal }\end{array}$ & 2 \\
\hline & $\begin{array}{l}\text { Menggunakan strategi yang tepat dalam menyelesaikan soal, lengkap } \\
\text { tetapi melakukan kesalahan dalam perhitungan atau penjelasan }\end{array}$ & 3 \\
\hline & $\begin{array}{l}\text { Menggunakan strategi yang tepat dalam menyelesaikan soal, lengkap } \\
\text { dan benar dalam melakukan perhitungan/penjelasan }\end{array}$ & 4 \\
\hline \multirow{5}{*}{ Inferensi } & Tidak membuat kesimpulan & 0 \\
\hline & $\begin{array}{l}\text { Membuat kesimpulan yang tidak tepat dan tidak sesuai dengan } \\
\text { konstek soal }\end{array}$ & 1 \\
\hline & $\begin{array}{l}\text { Membuat kesimpulan yang tidak tepat meskipun disesuaikan dengan } \\
\text { konsteks soal }\end{array}$ & 2 \\
\hline & $\begin{array}{l}\text { Membuat kesimpulan dengan tepat, sesuai dengan konteks tetapi } \\
\text { tidak lengkap }\end{array}$ & 3 \\
\hline & $\begin{array}{l}\text { Membuat kesimpulan dengan tepat, sesuai dengan konteks soal dan } \\
\text { lengkap }\end{array}$ & 4 \\
\hline
\end{tabular}


Adapun cara perhitungan nilai persentase adalah sebagai berikut:

$$
\text { Nilai Persentase }=\frac{\text { Skor Perolehan }}{\text { Skor Maksimal }} \times 100 \%
$$

Selanjutnya perolehan nilai persentase dimasukkan ke dalam kategori kemampuan berpikir kritis matematis siswa (Karim, 2015)

Tabel 3.Kategori Kemampuan Berpikir Kritis Matematis Siswa

\begin{tabular}{cc}
\hline Interpretasi (\%) & Kategori \\
\hline $81,25<X \leq 100$ & Sangat tinggi \\
$71,5<X \leq 81,25$ & Tinggi \\
$62,5<X \leq 71,5$ & Sedang \\
$43,75<X \leq 62,5$ & Rendah \\
$0<X \leq 43,75$ & Sangat rendah \\
\hline
\end{tabular}

Penelitian ini dianalisis dengan koefisien korelasi sederhana yang digunakan untuk mengetahui arah hubungan antara dua variabel. Korelasi yang digunakan adalah hubungan Pearson Product Moment dengan rumus (Siregar, 2014):

$$
r=\frac{n\left(\sum x y\right)-\sum x \cdot \sum y}{\sqrt{\left[n \sum x^{2}-\left(\sum x\right)^{2}\right]\left[n \sum y^{2}-\left(\sum y\right)^{2}\right]}}
$$

$n=$ jumlah data (responden)

$x=$ variabel bebas

$y=$ variabel terikat

Tahapan yang dilakukan untuk uji signifikan adalah sebagai berikut: 1) Membuat hipotesis dalam bentuk kalimat; $H_{0}$ (terdapat hubungan yang tidak signifikan antara game online dengan kemampuan berpikir kritis matematis siswa), dan $H_{a}$ (ada hubungan yang signifikan antara game online dengan kemampuan berpikir kritis matematis siswa), 2) Menentukan risiko kesalahan atau taraf signifikan $(\alpha)$, 3) Menggunakan kaidah pengujian, Jika $-t_{\text {tabel }} \leq t_{\text {hitung }} \leq t_{\text {tabel }}$ maka $H_{0}$ diterima dan jika $t_{\text {hitung }}>t_{\text {tabel }}$, maka $H_{0}$ ditolak.

\section{HASIL}

Data untuk menentukan siswa sebagai pecandu atau tidak terhadap game online, dilakukan dengan menggunakan angket tertutup. Angket disebarkan kepada sampel sebanyak 29 siswa kelas VIII SMP N 1 Ampek Angkek. Angket ini menggunakan skala likert yang terdiri dari pernyataan positif dan negatif, dengan memilih salah satu alternatif jawaban yaitu selalu (SL), sering (SR), kadang-kadang (KD), jarang (JR) dan tidak pernah (TP). Untuk pernyataan positif diberikan skor yaitu $\mathrm{SL}=5, \mathrm{SR}=4, \mathrm{KD}=3, \mathrm{JR}=2, \mathrm{TP}=1$. Sedangkan, untuk pernyataan negatif diberikan skor yaitu $\mathrm{SL}=1, \mathrm{SR}=2, \mathrm{KD}=3, \mathrm{JR}=4, \mathrm{TP}=5$. Selanjutnya diperoleh perolehan skor yang dapat dilihat pada tabel 4. 
Tabel 4. Total Perolehan Skor Angket Game Online

\begin{tabular}{cc|cc}
\hline Siswa & Skor & Siswa & Skor \\
\hline 1 & 170 & 16 & 156 \\
2 & 145 & 17 & 158 \\
3 & 157 & 18 & 157 \\
4 & 160 & 19 & 160 \\
5 & 153 & 20 & 167 \\
6 & 161 & 21 & 148 \\
7 & 149 & 22 & 164 \\
8 & 165 & 23 & 147 \\
9 & 142 & 24 & 176 \\
10 & 159 & 25 & 174 \\
11 & 162 & 26 & 163 \\
12 & 146 & 27 & 154 \\
13 & 155 & 28 & 152 \\
14 & 139 & 29 & 132 \\
15 & 169 & & \\
\hline
\end{tabular}

Berdasarkan skor angket game online yang diperoleh siswa maka ditentukan siswa yang kecanduan terhadap game online berdasarkan Kriteria Brown (Jenab \& Hudaya, 2015) yangdapat dilihat pada tabel 5 .

Tabel 5. Kecanduan Game Online versi Brown

\begin{tabular}{|c|c|c|c|c|c|c|c|}
\hline Siswa & $S$ & E & C & $T$ & $\mathbf{W}$ & $\mathbf{R}$ & K \\
\hline 1 & $83 \%$ & $89 \%$ & $91 \%$ & $92 \%$ & $80 \%$ & $93 \%$ & 6 \\
\hline 2 & $63 \%$ & $91 \%$ & $60 \%$ & $80 \%$ & $60 \%$ & $87 \%$ & 3 \\
\hline 3 & $83 \%$ & $86 \%$ & $67 \%$ & $88 \%$ & $65 \%$ & $100 \%$ & 4 \\
\hline 4 & $71 \%$ & $91 \%$ & $71 \%$ & $88 \%$ & $75 \%$ & $93 \%$ & 3 \\
\hline 5 & $71 \%$ & $89 \%$ & $78 \%$ & $72 \%$ & $70 \%$ & $87 \%$ & 2 \\
\hline 6 & $74 \%$ & $89 \%$ & $84 \%$ & $88 \%$ & $75 \%$ & $87 \%$ & 4 \\
\hline 7 & $63 \%$ & $94 \%$ & $62 \%$ & $76 \%$ & $75 \%$ & $87 \%$ & 2 \\
\hline 8 & $80 \%$ & $94 \%$ & $87 \%$ & $72 \%$ & $80 \%$ & $93 \%$ & 5 \\
\hline 9 & $63 \%$ & $86 \%$ & $62 \%$ & $80 \%$ & $60 \%$ & $87 \%$ & 3 \\
\hline 10 & $71 \%$ & $89 \%$ & $78 \%$ & $88 \%$ & $75 \%$ & $80 \%$ & 3 \\
\hline 11 & $77 \%$ & $83 \%$ & $80 \%$ & $84 \%$ & $85 \%$ & $100 \%$ & 5 \\
\hline 12 & $63 \%$ & $89 \%$ & $60 \%$ & $76 \%$ & $75 \%$ & $87 \%$ & 2 \\
\hline 13 & $71 \%$ & $89 \%$ & $73 \%$ & $88 \%$ & $70 \%$ & $80 \%$ & 3 \\
\hline 14 & $60 \%$ & $94 \%$ & $56 \%$ & $84 \%$ & $60 \%$ & $67 \%$ & 2 \\
\hline 15 & $80 \%$ & $83 \%$ & $80 \%$ & $96 \%$ & $100 \%$ & $93 \%$ & 6 \\
\hline 16 & $77 \%$ & $89 \%$ & $69 \%$ & $92 \%$ & $65 \%$ & $100 \%$ & 3 \\
\hline 17 & $83 \%$ & $83 \%$ & $67 \%$ & $96 \%$ & $65 \%$ & $100 \%$ & 4 \\
\hline 18 & $86 \%$ & $91 \%$ & $62 \%$ & $92 \%$ & $75 \%$ & $87 \%$ & 4 \\
\hline 19 & $71 \%$ & $86 \%$ & $78 \%$ & $88 \%$ & $75 \%$ & $93 \%$ & 3 \\
\hline 20 & $71 \%$ & $94 \%$ & $89 \%$ & $92 \%$ & $80 \%$ & $80 \%$ & 5 \\
\hline 21 & $66 \%$ & $89 \%$ & $67 \%$ & $84 \%$ & $75 \%$ & $80 \%$ & 3 \\
\hline 22 & $89 \%$ & $86 \%$ & $78 \%$ & $92 \%$ & $70 \%$ & $87 \%$ & 4 \\
\hline 23 & $66 \%$ & $91 \%$ & $64 \%$ & $76 \%$ & $75 \%$ & $80 \%$ & 2 \\
\hline 24 & $89 \%$ & $89 \%$ & $84 \%$ & $96 \%$ & $90 \%$ & $93 \%$ & 6 \\
\hline 25 & $97 \%$ & $83 \%$ & $87 \%$ & $88 \%$ & $85 \%$ & $100 \%$ & 6 \\
\hline 26 & $74 \%$ & $89 \%$ & $80 \%$ & $92 \%$ & $70 \%$ & $100 \%$ & 4 \\
\hline 27 & $77 \%$ & $86 \%$ & $73 \%$ & $80 \%$ & $75 \%$ & $87 \%$ & 3 \\
\hline 28 & $69 \%$ & $89 \%$ & $76 \%$ & $88 \%$ & $65 \%$ & $80 \%$ & 3 \\
\hline 29 & $63 \%$ & $83 \%$ & $56 \%$ & $56 \%$ & $70 \%$ & $80 \%$ & 2 \\
\hline
\end{tabular}


Keterangan:

$\mathrm{S}$ : Salience, E : Euphoria, C : Conflict, $\mathrm{T}$ :Tolerance, W : Withdrawal, R: Relapse and reinstatement, $\mathrm{K}$ : Kriteria Terpenuhi.

Kriteria yang terpenuhi pada tabel 5 diambil 80\% dari persentase perolehan skor angket siswa sehingga siswa yang memenuhi kriteria Brown sebagai pecandu game online minimal 3 dari 6 kategori didapatkan sebanyak 23 siswa dari 29 siswa yang merupakan pecandu game online menurut Brown

Data tentang kemampuan berpikir kritis siswa dikumpulkan menggunakan tes yang berbentuk essay. Setiap soal essay sesuai dengan indikator kemampuan berpikir kritis matematis siswa yang di adaptasi oleh Facione. Berdasarkan indikator maka didapatkan persentase kemampuan berpikir kritis matematis siswa yang diadaptasi dari Facione (Karim, 2015) yang dapat dilihat pada tabel 6.

Tabel 6. Persentase Kemampuan Berpikir Kritis Matematis Siswa

\begin{tabular}{cc|cc}
\hline Siswa & Persentase & Siswa & Persentase \\
\hline 1 & 62,50 & 16 & 50,00 \\
2 & 68,75 & 17 & 59,38 \\
3 & 56,25 & 18 & 78,13 \\
4 & 40,63 & 19 & 56,25 \\
5 & 46,88 & 20 & 59,38 \\
6 & 78,13 & 21 & 56,25 \\
7 & 46,88 & 22 & 50,00 \\
8 & 68,75 & 23 & 53,13 \\
9 & 84,38 & 24 & 71,88 \\
10 & 62,50 & 25 & 37,50 \\
11 & 56,25 & 26 & 81,25 \\
12 & 56,25 & 27 & 87,50 \\
13 & 43,75 & 28 & 84,38 \\
14 & 62,50 & 29 & 37,50 \\
15 & 59,38 & & \\
\hline
\end{tabular}

Setelah diperoleh persentase kemampuan berpikir kritis matematis siswa kemudian dimasukkan ke dalam kategori kemampuan berpikir kritis matematis siswa (Karim, 2015) pada tabel 7.

Tabel 7. Kategori Kemampuan Berpikir Kritis Matematis Siswa

\begin{tabular}{ccc}
\hline Interpretasi (\%) & Jumlah siswa & Kategori \\
\hline $81,25<X \leq 100$ & 4 & Sangat tinggi \\
$71,5<X \leq 81,25$ & 3 & Tinggi \\
$62,5<X \leq 71,5$ & 5 & Sedang \\
$43,75<X \leq 62,5$ & 14 & Rendah \\
$0<X \leq 43,75$ & 3 & Sangat rendah \\
\hline
\end{tabular}

Maka dari tabel di atas di dapatkan siswa yang memiliki kategori kemampuan sangat tinggi dengan rentang 81,25 $<X \leq 100$ sebanyak 4 siswa, kategori tinggi dengan rentang $71,5<X \leq 81,25$ sebanyak 3 siswa, kategori sedang dengan rentang 62,5 $<X \leq 71,5$ sebanyak 5 siswa, kategori rendah dengan rentang 43,75 $<X \leq 62,5$ sebanyak 14 siswa dan kategori sangat rendah dengan rentang $0<X \leq 43,75$ sebanyak 3 siswa.Berdasarkan angket dan kemampuan berpikir kritis matematis siswa didapatkan data siswa pada tabel 8 . 
Tabel 8. Pengelompokkan Siswa yang Bermain Game Online dengan Perolehan Hasil Kemampuan Berpikir Kritis Matematis Siswa

\begin{tabular}{|c|c|c|c|}
\hline Siswa & Jumlah Skor Angket & $\begin{array}{l}\text { Kriteria Pecandu } \\
\text { Terpenuhi }\end{array}$ & $\begin{array}{c}\text { Persentase Kemampuan } \\
\text { Berpikir Kritis }\end{array}$ \\
\hline 1 & 170 & 6 & 62,50 \\
\hline 2 & 145 & 3 & 68,75 \\
\hline 3 & 157 & 4 & 56,25 \\
\hline 4 & 160 & 3 & 40,63 \\
\hline 5 & 153 & 2 & 46,88 \\
\hline 6 & 161 & 4 & 78,13 \\
\hline 7 & 149 & 2 & 46,88 \\
\hline 8 & 165 & 5 & 68,75 \\
\hline 9 & 142 & 3 & 84,38 \\
\hline 10 & 159 & 3 & 62,50 \\
\hline 11 & 162 & 5 & 56,25 \\
\hline 12 & 146 & 2 & 56,25 \\
\hline 13 & 155 & 3 & 43,75 \\
\hline 14 & 139 & 2 & 62,50 \\
\hline 15 & 169 & 6 & 59,38 \\
\hline 16 & 156 & 3 & 50,00 \\
\hline 17 & 158 & 4 & 59,38 \\
\hline 18 & 157 & 4 & 78,13 \\
\hline 19 & 160 & 3 & 56,25 \\
\hline 20 & 167 & 5 & 59,38 \\
\hline 21 & 148 & 3 & 56,25 \\
\hline 22 & 164 & 4 & 50,00 \\
\hline 23 & 147 & 2 & 53,13 \\
\hline 24 & 176 & 6 & 71,88 \\
\hline 25 & 174 & 6 & 37,50 \\
\hline 26 & 163 & 4 & 81,25 \\
\hline 27 & 154 & 3 & 87,50 \\
\hline 28 & 152 & 3 & 84,38 \\
\hline 29 & 132 & 2 & 37,50 \\
\hline
\end{tabular}

Pada tabel 8 di atas dapat dilihat (perhatikan angka yang bergaris bawah) bahwa siswa yang merupakan pecandu game online memiliki tingkat kemampuan berpikir kritis yang beragam. Empat orang siswa yang memenuhi minimal 3 kriteria pecandu dengan nilai 81,25 - 100 dikatakan pecandu namun persentase kemampuan berpikir kritisnya menunjukkan interpretasi dengan kategori yang sangat tinggi, tiga orang siswa dengan nilai 71,5-81,25 dikatakan pecandu dengan interpretasi kategori tinggi, dan empat orang siswa dengan nilai $62,5-71,5$ menunjukkan interpretasi dengan kategori sedang. Hal ini menunjukkan bahwa siswa yang bermain game online dan bahkan dikatakan candu dalam bermain game online memiliki kemampuan berpikir kritis sedang sampai dengan sangat tinggi. Walaupun ada siswa yang merupakan pecandu namun kemampuan berpikir kritis nya sangat rendah

Hubungan game online dengan kemampuan berpikir kritis siswa kelas VIII SMP N 1 Ampek Angkek dilakukan perhitungan manual dan juga dengan menggunakan SPSS versi 16 yang hasilnya dapat diketahui bahwa taraf signifikansi antara variabel game online dan variabel kemampuan berpikir kritis matematis siswa yaitu $t_{\text {hitung }}=0,35844$ dibulatkan menjadi 0,36 dengan $r_{\text {hitung }}$ adalah 0,068, maka dapat disimpulkan terdapat hubungan yang tidak signifikan antara game online dengan kemampuan berpikir kritis matematis siswa.

Adapun tingkat hubungan kedua variabel penelitian ini berdasarkan interpretasi koefisien hubungan nilai $\mathrm{r}$ yaitu pada tingkat 0,00<0,068<0,199 sehingga hubungan antara kedua variabel sangat rendah atau sangat lemah. Hubungan game online terhadap kemampuan 
berpikir kritis siswa kelas VIII SMP N 1 Ampek Angkek terlihat dari nilai koefisiensi determinansi antara variabel game online dan variabel kemampuan berpikir kritis matematis siswa sebesar 0,47\%. Angka ini menunjukkan bahwa 0,47\% kemampuan berpikir kritis siswa ditentukan oleh bermain game online, selebihnya di tentukan oleh hal lain.

\section{PEMBAHASAN}

Dari hasil penelitian kemampuan berpikir kritis matematis siswa diperoleh nilai rata-rata keseluruhan adalah 60,56 yang berada pada interpretasi kemampuan berpikir kritis matematis dengan kategori Rendah. Dengan demikian pernyataan Smyth yang menyatakan bahwa "permainan yang kompleks dapat mengarahkan pada keberhasilan akademis dengan melibatkan pemain dalam pemecahan masalah, pemikiran kritis dan kreativitas", tidak bisa diterapkan atau di gunakan, hal ini juga tergantung dengan si pemain game online. Apabila si pemain game online dapat membagi waktu antara belajar dan bermain game online, walaupun dia dikatakan pecandu namun hasil yang diperoleh bisa meningkatkan kemampuan berpikir kritis matematis siswa tersebut.

Hal ini juga didukung dalam bukunya Ayu Rini dengan penelitian yang dilakukan oleh peneliti dari Universitas Rochestes, New York terhadap para pecandu game online yang menyatakan bahwa prestasi mereka disekolah terbilang bagus dan tidak terganggu dengan hobi mereka dalam bermain game. Hasil yang didapatkan dari penelitian ini, siswa yang bermain game online cenderung memperoleh nilai $<68$ walaupun masih ada beberapa siswa yang memperoleh nilai $>$ 68. Ini membuktikan bahwa siswa yang bermain game online bahkan sudah dikatakan candu dapat memberikan hasil yang tidak memuaskan. Beberapa siswa walaupun mereka memainkan game online dan mereka bisa membagi waktu mereka antara bermain game online dengan belajar, ternyata hasilnya tidak terlalu buruk. Berdasarkan tanya jawab dengan salah seorang siswa yang mengatakan bahwa pemain game online berkesempatan memperoleh nilai yang baik, apabila si pemain tetap melaksanakan tugas dan kewajibannya sebagai pelajar dan hal ini dilaksanakan setelah bermain game online.

\section{KESIMPULAN}

Berdasarkan hasil penelitian yang telah dilakukan tentang hubungan game online dengan kemampuan berpikir kritis matematis siswa kelas VIII SMP N 1 Ampek Angkek tahun pelajaran 2018/2019 diperoleh kesimpulan ada hubungan tapi tidak signifikan antara game online dengan kemampuan berpikir kritis matematis siswa kelas VIII SMP N 1 Ampek Angkek. Hubungan game online dengan kemampuan berpikir kritis matematis siswa tidak signifikan dikarenakan lebih dari $50 \%$ siswa pemain game online memperoleh interpretasi kemampuan berpikir kritis matematis berkategori rendah dan sangat rendah.

Berdasarkan kesimpulan dari penelitian ini, peneliti memilik bebrap rekomendasi sebagai berikut: (1) Bagi siswa bermain game online secukupnya tetapi siswa harus menomorsatukan belajar sebagai tanggungjawab seorang pelajar. (2) Apabila siswa ingin memainkan game online disarankan memainkan game online yang berbasis strategi serta melibatkan pemain dalam pemecahan masalah

\section{REFERENSI}

Effendi, A., \& Junaidi, B. P. (2014). Pengaruh Penggunaan Teknologi Informasi terhadap Aktivitas Fisik Siswa (Studi pada SMK Negeri 8 Surabaya Kelas X). Jurnal Pendidikan Olahraga Dan Kesehatan, 2(3), 605-608. Retrieved from http://ejournal.unesa.ac.id/index.php/jurnal-pendidikan-jasmani/issue/archive

Hanum, K. (2013). , Aktivitas Game Online Siswa SD (Kelas 3-6) Studi Deskriptif Di Warnet Kelurahan Gunung Anyar Kota Surabaya, 4, 5032770.

Ikhsan, M., \& Rizal, S. (2014). Penerapan Model Pembelajaran Berbasis Masalah untuk Meningkatkan Kemampuan Berpikir Kritis dan Disposisi Matematis Siswa. Jurnal 
Didaktik Matematika, Vol. 1, 71-82. https://doi.org/10.1039/b908937c

Jenab, \& Hudaya, A. (2015). Adiktif Game Online. Research and Development Journal Of Education, 2(1), 41-52.

Jumaisyaroh, T., Napitupulu, E. E., \& Hasratuddin, H. (2015). Peningkatan Kemampuan Berpikir Kritis Matematis Dan Kemandirian Belajar Siswa Smp Melalui Pembelajaran Berbasis Masalah. Kreano, Jurnal Matematika Kreatif-Inovatif, 5(2), 157. https://doi.org/10.15294/kreano.v5i2.3325

Karim, N. (2015). Kemampuan Berpikir Kritis Siswa Dalam Pembelajaran Matematika Dengan Menggunakan Model Jucama Di Sekolah Menengah Pertama,3(April).

Rini, A. (2011). Menanggulangi Kecanduan Game Online Pada Anak (1st ed.). Jakarta: Pustaka Mina.

Seifi, M. (2015). The Effect of Computer Games on Students' Critical Thinking Disposition and Educational Achievement. International Journal of Education and Literacy Studies, 3(4). https://doi.org/10.7575/aiac.ijels.v.3n.4p.36

Siregar, S. (2014). Statistik Parameter Untuk Penelitian Kuantitatif. Jakarta: PT: Bumi Aksara.

Surbakti, K. (2017). Pengaruh Game Online Terhadap Remaja, 1(1), 28-38.

Wewe, M. (2017). Jurnal Math Educator Nusantara (JMEN ) Upaya Meningkatkan Kemampuan Berpikir Kritis Matematika dengan Problem Posing pada Siswa Kelas VIII SMP Negeri 4 Golewa Tahun Ajaran 2016 / 2017. Jurnal Math Educator Nusantara (JMEN), 3(1), 1-57.

Wright, J. (2011). The effects of video game play on the academic performance. Modern Psychological Studies, 17(1), 37-44. https://doi.org/10.1016/j.visres.2014.07.010 